\title{
The young Romanian managers circumstance in investition times
}

\author{
Dan Stefanov ${ }^{*}$
}

Rescopa SA is a company using private capital whose fields of activity are trade and nourishment. This is its 40th year of activity. Rescopa is a full member of the Food Business Forum and founding member of the Romanian Committee of Distribution.

Our company current activity consists in producing and trading food consumers goods (about $40 \%$ of the products sold through its own food laboratories). The distribution network consists of 12 restaurants, 6 confectioneries, 10 pastry shops, 7 food shops and the most important of all, 1 Cash \& Carry type wholesale center. Our products are made in 8 cooking laboratories, 6 confectionery laboratories, 4 pastry laboratories, 4 bakeries, one butchery and a soft drink factory.

We can talk about our distribution networks expansion over the boundaries of our country in 3 towns of other countries (districts). Our intention is to expand it even more so that in 1997, we should be able to talk about „attacking“ Bucharest (the Romanian capital) market. At present the network of Rescopa is formed of 38 units, but in 1997 we want to duplicate this. Being a member of the Food Business Forum our companies policy is to continuously adapt both its distribution and production to Western standards. The first step in achieving this goal was modernising its production and market places.

The second step was searching for its own identity some special things to make it different, to make it emerge from among its rivals. One of the most important achievements of the company was the creation of a new concept of shop „the conglomerate type shop“, a concept in accordance with the international tendency of specialising a supermarket in small and medium shops, but adapted to the Romanian market.

The concept of „conglomerate type shop“ includes all the 7 categories of products we usually find in Western shops: grocery - cosmetics and detergents meat and meat consumer good fruits and vegetables. Among these specialised departments, this shop includes a confectionery and pastry department. After the example given by the McDonald's - that managed by creating an unique concept

\footnotetext{
Dan Stefanov, born 1968, Chief of Marketing Department at Resopa SA.
} 
of restaurant, to expand all over the world - Rescopa intends on the basis of its concept of „conglomerate type shop“ to nationally expand its network.

Expanding its distribution network means expanding, at the same time, its capacity of production. Its management policy is to assure at least $40 \%$ of the food stuff to be sold in its shop, so that the amount of money gained should be doubled.

A very special chapter in our company's activity is that of establishing a joint venture company with a German partner's help whose field of activity is production. Speaking about our company's collaboration with other partners, the financial results up to now make us affirm this is one of the most viable ways of developing and obtaining future profit.

Till 1994 Rescopa was a state company but after that it became private. The MEB method - of selling stocks to its own employees - was both the element that assured our company's survival and development as a whole and the way of replacing centralism with private initiative. In spite of the restrictive law frame and in spite of a banking policy to dishearten free initiative and the development of the industrial units, Rescopa SA managed an adequate managerial and marketing policy to increase its profit: From 0,6 billion lei in 1991 to 5,3 billion lei in 1995 and about 15 billion in 1996.

Being a member of the Food Business Forum, the organisational structure of our company was adapted to Western standards by creating new departments such as selling, merchandising and marketing.

I am the one who leads the marketing department and I'm in charge of supervising the way of promotion of the entire range of products - beginning with the ways of exhibition in shelves, promotion, advertising, deciding a price watching the evolution of the products during the period of beginning stationed inside the shop, planning the supplies and ending with analysing if selling products or a range of products may bring a profit or not. I'm very preoccupied with promotion and supervising our own company's products. The department I lead includes 3 other departments: marketing, merchandising and selling.

The marketing department is in charge of studying the market, the conveyor, the rivals, the influence of the perturbative factors and of finding ways of influencing or counteracting them. Studying the marketing includes activities of promotion and advertising too.

The merchandising department is in charge of the right administration of the product, the way and the place of tidying it on the shelf, the way of dividing the shop in departments, the way of promoting the product.

The selling department is in charge of supervising the evolution of a product or a range of products, beginning with the moment of its introduction in shop and ending with the moment of its selling. Watching a product means a great 
flexibility and rapidity in making the policy of prices and accurate accounting of the profit a precise decision regarding the moment of buying supplies.

Even if this may seem hard to be done, merging these 3 departments has beneficent effects both from the point of view of the clarity and concomitance of the action and of the easing of quantifying results and effects. A slow selling of a certain range of products may be result of an inadequate exhibition on the self or a inadequate policy of the trade or price, a wrong advertising or a wrong identification of a need. If separated, even if rapidly communicating the sales marketing and merchandising departments suffered from belated decision destined to make the whole system work. Talking about Rescopa SA, the merger of these 3 departments in a single one has nothing but beneficent effects on both the speed of reaction and the quality of the decision (the decision can't be the result of some distorted information).

Taken all round, the activity of the department I lead is structured after the strategy of maximum efficiency, a strategy whose basis consist in:

1. What I sell-produce-do in order to increase the efficiency of sales and production - and what purpose I have

2. How I want to penetrate the market-sell-administrative the products-control and increase the efficiency of my sales - make myself distinct among rivals-act and control my work in order to do it better - modify my policy of promotion and prices-realise if administrating a product or business may bring a profit or not- quantify and counteract the disturbing effects.

3. When is better to penetrate the market - modify what I sell or produce modify my promotional activities - advertising modify my policy of prices stop producing or selling something.

4. To whom I sell - I appeal when advertising - I commission the tasks.

5. How long I want to sell - use the same promotional activities - keep the same policy of advertising and prices - how much I want to spend for each activity how much time I intend to allot to every activity.

If I'm able to give an answer to each of these questions I can easily make a marketing plan, find solutions to solve the specific problems! My only headache is to verify and modify the plan every week.

On of the most pressing problems I have to face is that of creating and maintaining the company's public image. This image must be a positive one, structured on the very important concept of quality (of the partnership products - service - management - marketing - employees and so on). Taking into account the slogan „Quality - our partner“ I managed by imposing one company's partnership this positive image to make of Resposa SA a company famous in the country for the quality of service, a company whose such is bigger after day. 
I can’t say I faced no problems. On the contrary, every day I must „fight“:

1. The mentality of my own employees: It is very difficult to make them understand that better services mean kind attitude and speech and better services mean more and more consumers.

2. The obstinacy of the consumer: If during the last 35 years the consumer was at the seller disposal, now the situation is exactly the opposite one. I think is pretty hard for him (the consumer) to get used to everything new in his life.

3. The limited resources: Because of the law that forces me to use only $5 \%$ from the gross profit in marketing activities, is very hard for me to make quick changes using so little money.

4. The disadvantaging banking policy: Public image means at the same time, an overall and a local one. Public image means great financial efforts but, if taking into account inflation and banking interests up to $70-80 \%$ an year, you realise it is pretty tough to make an investment whose profit will come after while.

5 . The immaturity proved by mass-media

How can I create the adequate public image for my company? By:

a) making my employees understand that their attitude and behaviour towards customers can bring profits and profits can bring a better life for them.

b) making my customers, business partners, rivals, mass-media community, government organisation think that the services I offer are the best. How can I do that? By offering them the best promotional actions, the best advertising, the best products, by participating on exhibition, by sponsorships and charity actions.

Taking into account all the obstacles I'm confronted with, I realise they are external and internal:

\section{Internal obstacles}

1. The human potential: Is very hard to find, even amongst people that just graduated someone to have enough knowledge and skills for working with success in the marketing field.

2. The logistic potential: Because the department I lead isn't adequately equipped, I must make appeal, for solving my specific problems, to the services offered by companies specialised in creating public images. But each of my requirements takes money and I can never be sure of the final results of their work.

3. The financial potential: Because of the small amount of money I have at my disposal, I must conduct my marketing actions on the principle: „minimum of financial efforts - maxim and immediate effects“. This is the reason why most of 
my action take little time and money so that I could say I'm doing a sort of guerrilla marketing.

4. The concurrence between the companies divisions: Another very influential factor is the domination of the productive activity over the marketing (maybe this problem has the most influence).

\section{External obstacles}

1. Consumers - The Romanian consumer feels himself seduced by cheap and glaringly pached products (made in Arabian or Asian countries) that, in most of the cases have no qualities. This is the reason why I must convince him that my products, even if not so cheap or glaring, are better, or doing this I need not only much money but also very much time. It really takes time to change someone's attitude even towards himself.

2. Business partners - Because every business partner wants a quick and maximum profit, the quality and price of the raw materials he offers leave much to be desired, I sometimes see myself forced to sell some products with minimum profit or no profit at all.

3. Rivals - There are two sorts of rivals: the Romanian and the foreign rivals: Speaking about the Romanian rivals I must say that I'm confronted with major prejudices caused by the disloyal behaviour of other companies or by their habit of making copies or even imitate the action developed by our company. Speaking about the foreign rivals I must say that they have a great deal of money to be spent in tremendous advertising campaigns destined to impose foreign products on the Romanian market. This is the reason why, in order to survive, my company is forced to use a small amount of money, to try to obtain the some results as the foreign rivals.

4. Financial institutions - The repressive policy of the financial institution, even if not acting over the marketing, constitutes a hindrance in developing because of its negative impact over the company activity.

5. Banking institutions - By demanding and exaggerating interest the banking institutions are real obstacles for those companies in full development.

6. Mass-Media - By superficially approaching some problems, by running after sensational subjects, by the great amounts of money they demand in exchange for their services, the mass-media representatives are rather passive collaborators for my company's marketing department.

7. Governmental and Non-Governmental organisations - Because there are many of them and because they have different or even opposite opinions and interest, these organisations are another real obstacle for the marketing activity. 
8. The economical factors - The reduced consumer power of buying, the hyperinflational status of the national currency impose further efforts, efforts that must materialise in a greater power of influencing the consumer.

9. The political factors - The existence of a wrong policy is directly influencing the status of the economy and implicitly the activity developed by my company. 